\title{
FINANCIAL KNOWLEDGE, FINANCIAL ATTITUDE, AND FINANCIAL MANAGEMENT BEHAVIOR: SELF-CONTROL AS MEDIATING
}

\author{
Indra Siswanti ${ }^{1}$ and Adiyati Mayang Halida ${ }^{2}$ \\ ${ }^{1}$ Faculty of Economics and Business, Mercu Buana University. \\ ${ }^{2}$ Program of Magister Management, Perbanas Institute.
}

\begin{abstract}
Purpose - This research aims to analyze the factors influencing financial management behavior in employees of Islamic University "45" Bekasi because financial behavior is a very important issue at this time.

Design/methodology/approach - The sampling technique used for this research is purposive sampling with the total population is 305 employees and samples taken were 81 employees. The data used primary data and analyzed data using smart PLS.
\end{abstract}

Findings - The results of the research state that financial knowledge has a significant effect on financial management behavior, the financial attitude has a significant effect on financial management behavior, self-control has a significant effect on financial management behavior, financial knowledge has a significant effect on self-control, the financial attitude has a significant effect on self-control, self-control mediated the partial effect of financial knowledge on financial management behavior, and self-control mediated the partial effect of financial attitudes on financial management behavior.

Practical Implications - Financial knowledge does affect Indonesian people on how they manage their financial behavior and attitude.

Originality/value - This research is related to the behavior of Indonesian people who tend to think short-term and tend to have a consumptive life pattern so that it often happens where someone with enough income but still has financial problems.

Keywords Financial knowledge, financial attitude, self-control, financial management behavior

Paper Type Research paper (case study)

Vol. 28, No. 01 April 2020

(c) Centre for Indonesian Accounting and Management Research Postgraduate Program, Brawijaya University 


\section{INTRODUCTION}

Management of financial behavior is a problem that is widely discussed in society, especially in regards to the consumptive behavior of people in Indonesia. Indonesian people tend to think short-term and do impulsive shopping practices. Indonesian people's shopping practices are more likely to fulfill their wants rather than their needs. Many individuals have sufficient income yet still experience financial problems, this is due to financial behavior that is less responsible. Irresponsible financial behavior is usually indicated by the lack of savings, investment, emergency fund planning, and budgeting for the future. Indonesian people have not saved optimally. According to Perry and Morris (2005), a person's responsibility for managing finances can be judged by their tendency to save money, manage budgets, and control spending.

Financial management behavior is considered as one of the most important concepts in financial disciplines. Financial management behavior as the determination, acquisition, allocation, and utilization of financial resources (Horne and Wachowicz, 2005). Kholilah and Iramani (2013) explained that financial management behavior is the ability to manage the planning, budgeting, checking, managing, controlling, seeking, and storing daily financial funds. Kholilah and Iramani (2013) state that the emergence of financial management behavior is the impact of a person's desire to meet their needs in accordance with the level of income. Besides financial management behavior, there are financial decision making and harmonization of individual motives.

Financial management behavior is influenced by many factors, such as financial knowledge, financial literacy, financial attitudes, and others. Lynne (2008) states that financial attitudes have a significant effect on financial management behavior while education level and financial knowledge does not affect financial management behavior. Prihartono and Asandimitra (2018) stated that financial knowledge, financial attitudes, and social demographics have a 
significant effect on financial deception behavior, while Herdjiono and Damanik (2016) stated that financial knowledge and parental income does not affect financial management behavior while financial attitudes have a significant effect on financial management.

On the other hand, financial attitude is a factor that needs to be considered in financial management behavior because in general, attitude towards money is defined as the behavior of an individual towards the money they own. Money is a primary need that can influence one's behavior and capable to make people think irrationally. Pankow (2003) states that financial attitudes are states of mind, opinions, and judgments about finance. Attitudes toward money have four dimensions including believing that money is a symbol of strength, money is important in life, money can cause suspicion and distrust of others, and money is a symbol of success.

Another factor that can influence financial management behavior is selfcontrol. Otto et al. (2007) states that in a financial context, self-control is an activity that can function to encourage someone to make savings and can reduce impulsive purchases. Chaplin (2002) defines self-control as the ability to guide one's behavior, related to one's ability to suppress or inhibit impulsive behavior. Camilla et al. (2017) state that self-control has a significant effect on consumer behavior. Herlindawati (2015) states that self-control has a significant positive effect on financial management.

A research conducted by Chandra (2009) analyzes the effect of competence of individual investors on their trading behavior in the stock market. This impacts their returns from their investments, their belief in the stock markets, and also the functioning of financial markets to some extent. Investors with a high level of competence tend to trade more frequently. While some factors affect individuals' perceptions towards external issues, some affect their belief in 
themselves, which in turn, influences their confidence and belief in their judgment and decision making. The research conducted by Wibisono (2013) stated that the competence and confidence of investors have a significant effect on stock trading. This is in line with the research of Graham et al. (2009) which states that when an investor feels competent, the investor will trade shares more frequently and will cause higher transaction frequency.

Chen-Chen et al. (2018) state that overconfidence is a characteristic that is often found in humans that reflects a person's tendency to overestimate estimates of his ability, the likelihood of success, and the probability that a person will obtain positive outcomes and accuracy of the knowledge possessed.

\section{LITERATURE REVIEW}

\subsection{Financial Knowledge}

According to Kholilah and Iramani (2013), financial knowledge is the knowledge that refers to what individuals know about personal financial matters as measured by their level of knowledge about various personal financial concepts. Financial knowledge is one's mastery of various things about the world of finance. Financial knowledge is knowledge to manage finances in financial decision making. Financial knowledge covers several aspects of finance, as follows:

a. Basic personal finance,

b. Money management,

c. Credit management,

d. Saving and investment,

e. Risk management.

\subsection{Financial Attitude}

According to Marsh (2006), financial attitudes refer to how a person feels about personal financial problems, as measured by responses to a statement or Vol. 28, No. 01 April 2020

(c) Centre for Indonesian Accounting and Management Research Postgraduate Program, Brawijaya University 
opinion Pankow (2003) that defines financial attitudes as states of mind, opinions, and judgments about finance. Shohib (2015) states there are 5 concepts regarding financial attitudes, as follows:
a. Power
b. Time
c. Distrust
d. Quality
e. Anxiety

\subsection{Self Control}

According to Naomi and Mayasari (2008), self-control is a response pattern that has just begun to replace something with another, for example, responses related to diverting attention from something desired, changing emotions holding back certain impulses and improving performance. self-control is the ability of individuals to refrain or direct themselves in a better direction when faced with temptations (Hofmann et al., 2012). Ghufron and Rini (2011) state that there are three aspects of self-control, as follows:
a. Behavior Control
b. Cognitive Control
c. Decisional Control

\subsection{Financial Management Behavior}

According to Horne and Wachowicz (2005), financial management behavior is the determination, acquisition, allocation, and utilization of financial resources. Mien and Thao (2015) state that financial management behavior is related to the effectiveness of fund management. Based on the above opinion it can be concluded that financial management behavior is a person's responsibility in regulating by taking into account management functions that function as the 
determination, acquisition, allocation, and utilization of financial resources. As follows:
a. Consumption
b. Cash flow management
c. Saving and investment
d. Credit management

\subsection{Theoretical Framework and Hypothesis}

From the research framework, it can be seen that there is an effect between independent variables and the dependent variable, and financial performance as an intervening variable.

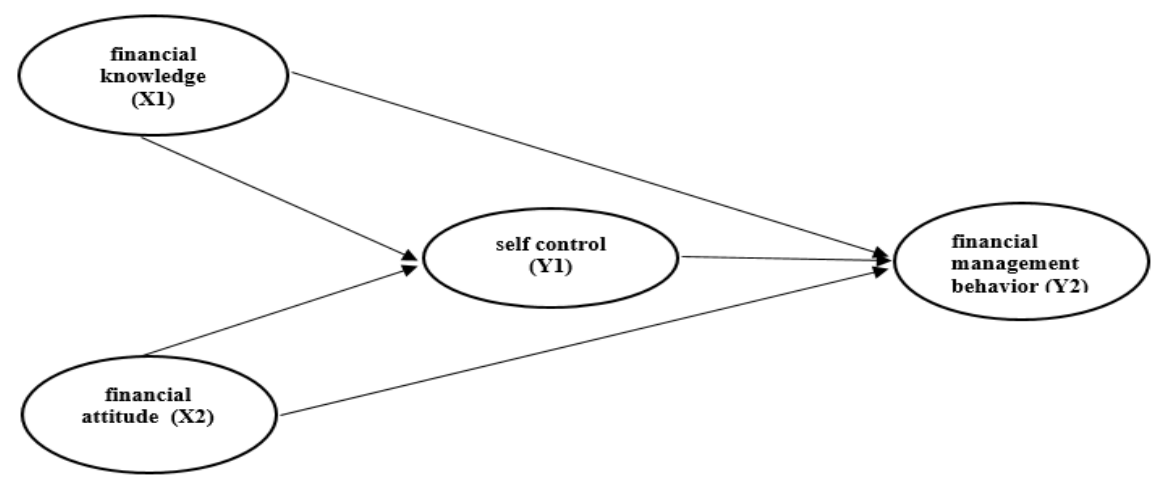

Figure 1. Research Framework

\subsubsection{Hypothesis}

Based on the background and results of research previously, the researchers suggested the following hypothesis:

\subsubsection{Financial Knowledge on Financial Management Behavior}

Knowledge refers to what individuals know about personal financial matters, as measured by their level of knowledge about various personal financial Vol. 28, No. 01 April 2020

(C) Centre for Indonesian Accounting and Management Research Postgraduate Program, Brawijaya University 
concepts (Marsh, 2006). The research of Sabri et al. (2008) state that financial knowledge has a significant effect on financial behavior. Hung et al. (2009), states that someone with low financial knowledge tends not to understand financial problems, lacks good financial behavior, and is less skilled in dealing with economic shocks. Financial knowledge is not only able to make someone use money wisely, but can also benefit the economy. Someone with higher financial knowledge will be able to make good decisions for their family and thus be in a position to improve their economic security and well-being, besides someone who has good financial knowledge will be able to make very important information choices for an effective market and efficient (Hilgert and Hogarth, 2003). Someone with good financial knowledge will better understand financial problems and have better financial behavior, so that, the better the knowledge of finance, the better someone is in managing their finances. Thus, the hypothesis proposed in this study is:

H1: Financial knowledge has a significant effect on financial management behavior

\subsubsection{Financial Attitude on Financial Management Behavior}

Financial knowledge is one's mastery of various things about the world of finance (Kholilah and Iramani, 2013). Meanwhile, financial management behavior refers to how a person behaves in personal financial matters, as measured by individual actions. Marsh (2006) states that a person's financial behavior arises from his financial attitude, individuals who are not wise in responding to personal financial problems tend to have bad financial behavior. Financial attitudes shape the way people spend, save, hoard, and spend money. Financial attitudes affect financial problems such as arrears in arrears and lack of income to meet needs. Short-term thinking and lack of willingness to save are 
attitude factors that can cause financial problems (Madern and Schors, 2012) Based on the explanation above it can be said that financial attitudes influence how a person regulates his financial behavior. Thus the hypothesis proposed in this study is:

H2: Financial attitude has a significant effect on financial management behavior

\subsubsection{Self-Control on Financial Management Behavior}

According to Chaplin (2011), the definition of self-control is the ability to guide one's behavior in terms of one's ability to suppress or impulse behavior. Self-control is related to how strong a person holds values and beliefs to be used as a reference when acting or making a decision. Self-control must be owned by every individual when they want to decide to owe. Chaplin (2011) states that a person can control spending by resisting the desire to spend excessive money or in other words a person spends money based on their wants and not their needs. Based on these explanations, the following hypothesis is proposed: H3: Self-control has a significant effect on financial management behavior

\subsubsection{Financial Knowledge on Self Control}

Chaplin (2011) states that self-control is the ability to guide one's behavior, the ability to suppress or impede impulsive behavior. In some financial cases many people cannot set aside money for the future, thus forgetting the long-term goal is only for temporary satisfaction because of the lack of individual selfdiscipline in controlling himself (Pompian, 2006). Self-control is influenced by several factors including cognitive factors, while knowledge, is a stage of cognitive. In this case, financial knowledge can affect self-control in financial management. Based on these explanations, the following hypothesis is proposed: H4: Financial knowledge has a significant effect on self-control 


\subsubsection{Financial Attitude on Self Control}

Attitude is a tendency to approach or avoid, positive or negative towards various social conditions, whether it is institutional, personal, situation, ideas, concepts and so on. Next explained that attitude has a relationship with aspects of motivation and feelings or emotions. Whereas the self-control process explains how the self regulates and controls behavior in running life according to the ability of individuals to control behavior, especially in financial management (Gerungan, 2000). Based on these explanations, the following hypothesis is proposed.

H5: Financial attitude has a significant effect on self-control

\subsubsection{Self Control Mediated Effect of Financial Knowledge on Financial Management Behavior}

Individuals with high financial knowledge can implement their knowledge in daily life in their financial management so that the behavior of debt management individuals is also good. Besides being able to direct effect on financial management behavior, financial knowledge can also indirectly affect financial management behavior mediated by several factors. One of them is the self-control variable. Kholilah and Iramani (2013) state that self-control is can mediate the effect of financial knowledge on financial behavior. Based on these explanations, the following hypothesis is proposed

H6: Self-control mediated effect of financial knowledge on Financial management behavior 


\title{
2.5.1.7 Self-control mediated the effect of financial attitudes on Financial management behavior
}

Understanding of financial attitudes can help a person to understand what is believed in relation to money. Therefore, the notion of financial attitude is defined as a state of mind, opinions, and judgments about finance. Pompian (2006) states the first aspect related to personality is a person's confidence in financial behavior, regardless of the approach to his career, his health, or his finances. This is a person's emotional state and confidence in several things. The second aspect of the approach relating to whether people think methodically, cautiously, and analytically in their financial behavior or investors are emotional, intuitive, and patient. For this, cell control is needed, this is related to emotional management in financial management, so self-control can be predicted to mediate the influence of financial attitudes on financial management behavior. Hypothesis 6: Self-control mediated effects of financial knowledge on financial management H7: Self-control mediated effect of financial attitudes on Financial management behavior

\section{METHODOLOGY}

The population in this study were all employees of the Islamic University of "45" Bekasi consisting of teaching staff and administrative staff totaling 305 employees. The sampling technique used was purposive sampling method. The employees that can be sampled are employees who have the criteria as follows: (1) Female employees (lecturers and employees); (2) Administrative staff, from middle management to top management (3) Teachers who have a Functional Position of at least Lector and have the status of Permanent Lecturers of the Foundation. Based on the criteria above, the number of samples was calculated by Slovin, obtained as 81 people. The data used in this study are primary data

\author{
Vol. 28, No. 01 April 2020 \\ (C) Centre for Indonesian Accounting and Management Research \\ Postgraduate Program, Brawijaya University
}


through questionnaires, interviews, and documentation. Operational variables in the study as shown in table 1.

Table 1. Operational Definition of Variable

\begin{tabular}{|c|c|c|c|}
\hline No & $\begin{array}{l}\text { Operational } \\
\text { Definition }\end{array}$ & Indicator & Measurement \\
\hline 1 & $\begin{array}{l}\text { Financial } \\
\text { knowledge }(\mathbf{X} \mathbf{1}) \\
\text { people's } \\
\text { understanding of } \\
\text { various things about } \\
\text { finance }\end{array}$ & $\begin{array}{l}\text { a. basic personal } \\
\text { finance } \\
\text { b. money management } \\
\text { c. credit and debt } \\
\text { management } \\
\text { d. saving and } \\
\text { investment } \\
\text { e. risk management }\end{array}$ & scale likert \\
\hline 2 & $\begin{array}{l}\text { Financial attitude } \\
\text { (X2) } \\
\text { a state of mind, } \\
\text { opinion, and } \\
\text { judgment about } \\
\text { finance }\end{array}$ & $\begin{array}{l}\text { a. power } \\
\text { b. time } \\
\text { c. distrust } \\
\text { d. quality } \\
\text { e. anxiety }\end{array}$ & scale likert \\
\hline 3 & $\begin{array}{l}\text { Self-control (Y1) } \\
\text { It is an individual's } \\
\text { tendency to consider } \\
\text { various } \\
\text { consequences for } \\
\text { certain behaviors }\end{array}$ & $\begin{array}{l}\text { a. Behavior Control } \\
\text { b. Cognitive Control } \\
\text { c. Decisional Control }\end{array}$ & scale likert \\
\hline 4 & $\begin{array}{l}\text { Financial } \\
\text { management } \\
\text { behavior (Y2) } \\
\text { ways to manage } \\
\text { funds owned related } \\
\text { to one's } \\
\text { responsibilities in } \\
\text { managing finances }\end{array}$ & $\begin{array}{l}\text { a. Consumption } \\
\text { b. Cash flow } \\
\text { management } \\
\text { c. Saving and } \\
\text { investment } \\
\text { d. Credit management }\end{array}$ & scale likert \\
\hline
\end{tabular}

The data analyzed using Smart Partial Least Square (PLS) software. The measurement model is used to test the validity and reliability, while the structural 
model is used to test causality (hypothesis testing with predictive models) Ghozali (2006).

\section{RESULT AND DISCUSSION}

\subsection{Test Validity and Reliability}

Validity and reliability tests for all variables in this research can be seen from the results of convergent validity, discriminant validity, and composite reliability, as shown in Table 2 below.

Table 2. Test Validity and Reliability

\begin{tabular}{|c|c|c|c|c|c|c|}
\hline \multirow[b]{2}{*}{$\begin{array}{c}\text { Variab } \\
\text { le }\end{array}$} & \multirow[b]{2}{*}{$\begin{array}{l}\text { Code } \\
\text { Indicator }\end{array}$} & \multicolumn{2}{|c|}{$\begin{array}{c}\text { Validity } \\
\text { Convergent }\end{array}$} & $\begin{array}{c}\text { Validity } \\
\text { Discrimin } \\
\text { ant }\end{array}$ & \multicolumn{2}{|c|}{ Reliability } \\
\hline & & $\begin{array}{l}\text { Loadi } \\
\text { ng } \\
\text { Factor }\end{array}$ & $\begin{array}{c}\mathrm{AV} \\
\mathrm{E}\end{array}$ & $\begin{array}{l}\text { Cross } \\
\text { Loading }\end{array}$ & $\begin{array}{l}\text { Cronbach } \\
\text { 's Alpha }\end{array}$ & $\begin{array}{c}\text { Composi } \\
\text { te } \\
\text { Reliabilit } \\
\mathrm{y}\end{array}$ \\
\hline \multirow{14}{*}{ 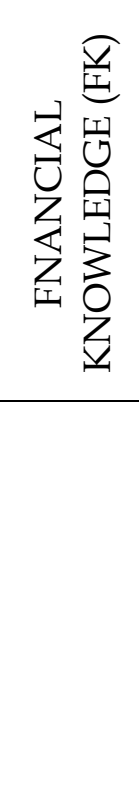 } & PK01 & 0.623 & \multirow{14}{*}{$\begin{array}{c}0.49 \\
7\end{array}$} & \multirow{14}{*}{0.705} & \multirow{14}{*}{0.943} & \multirow{14}{*}{0.949} \\
\hline & PK10 & 0.667 & & & & \\
\hline & PK11 & 0.719 & & & & \\
\hline & PK12 & 0.717 & & & & \\
\hline & PK13 & 0.699 & & & & \\
\hline & PK14 & 0.749 & & & & \\
\hline & PK15 & 0.546 & & & & \\
\hline & PK16 & 0.709 & & & & \\
\hline & PK17 & 0.743 & & & & \\
\hline & PK19 & 0.664 & & & & \\
\hline & PK02 & 0.643 & & & & \\
\hline & PK20 & 0.656 & & & & \\
\hline & PK03 & 0.682 & & & & \\
\hline & PK04 & 0.706 & & & & \\
\hline
\end{tabular}

Vol. 28, No. 01 April 2020

(C) Centre for Indonesian Accounting and Management Research Postgraduate Program, Brawijaya University 


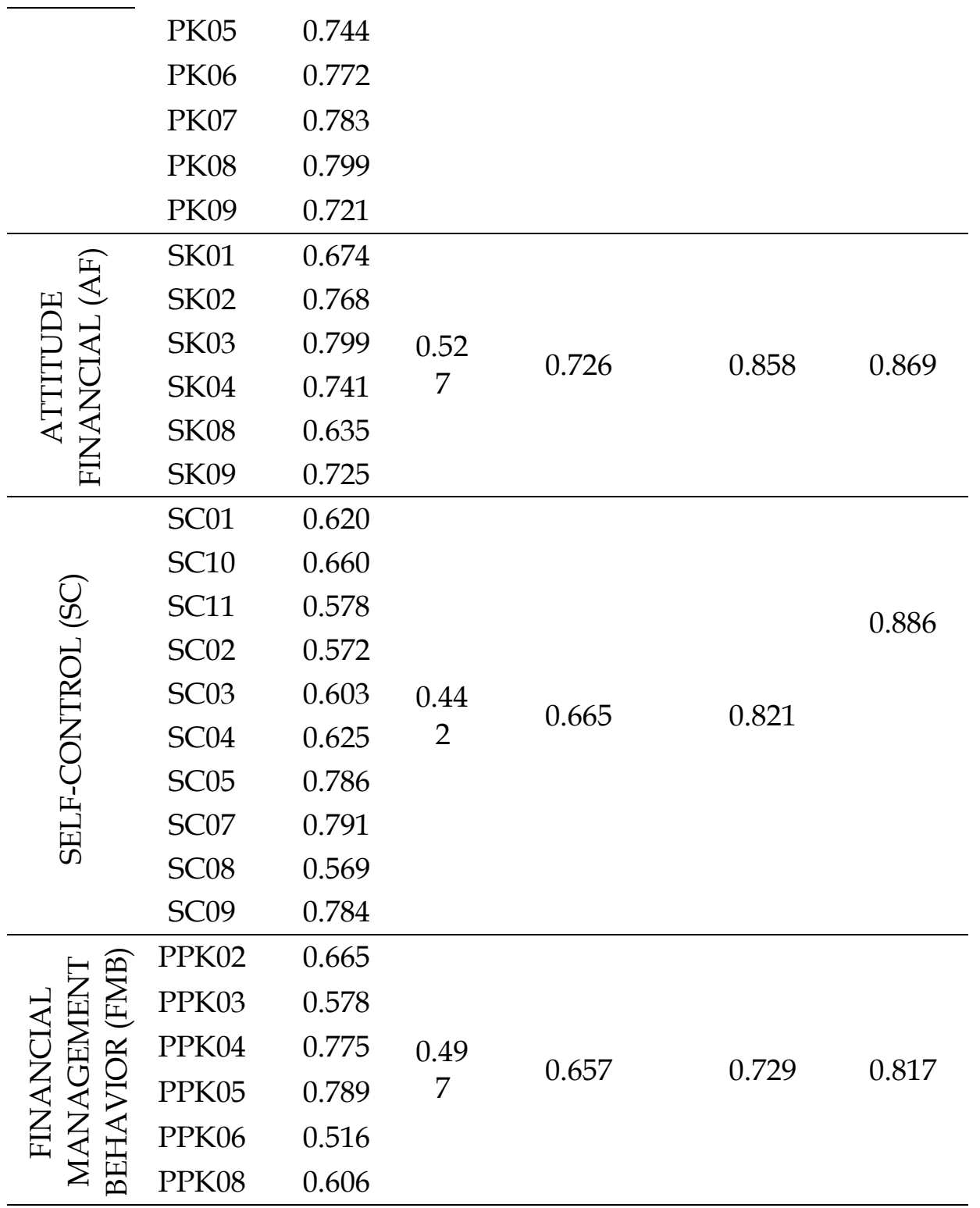

Source: data processed

Based on table 2, the results of tests of convergent financial knowledge, financial attitudes, self-control, and financial management behavior, indicate that the external loading indicator variable has a value $>0.50$, so it can be concluded

Vol. 28, No. 01 April 2020

(C) Centre for Indonesian Accounting and Management Research Postgraduate Program, Brawijaya University 
that the measurement indicators for the variables of financial knowledge, financial attitudes, self-control, and financial management behavior have met the convergent validity test. Discriminant validity test results can be seen from the square root value of the average variance extracted (AVE), from table 2 it can be seen that the AVE value of each variable has an AVE value that is higher than the correlation value among other constructs, it can be stated that all variable has high discriminant validity.

The reliability test used two approaches, namely Cronbach's alpha and composite reliability. Cronbach's alpha test results require that all variables have a minimum value of 0.70 , and for the composite reliability test all variables have a minimum of 0.60 . From table 2 it can be stated that the variables of financial knowledge, financial attitudes, self-control, and financial management behavior have a Cronbach's alpha value above 0.70 and a composite reliability value above 0.60. Thus all variables are stated reliable.

\subsubsection{The Goodness of Fit Test}

The results of data analysis with smart PLS 3.0, obtained R-Square values as follows:

Table 3, R-Square test

\begin{tabular}{lc}
\hline \multicolumn{1}{c}{ Variable } & R-Square \\
\hline Financial management behavior (FMB) & 0.561 \\
\hline Self-control (SC) & 0.406 \\
\hline
\end{tabular}

Source: data processed

The results of the calculation of Q Square are as follows:

$$
\begin{aligned}
\text { Q-Square } & =1-\left[\left(1-\mathrm{R}^{2} 1\right) \times\left(1-\mathrm{R}^{2} 2\right)\right] \\
& =1-[(1-0.561) \times(1-0.406)]
\end{aligned}
$$




$$
\begin{aligned}
& =1-(0.439 \times 0.594) \\
& =1-0.260 \\
& =0.739
\end{aligned}
$$

The calculation results show prediction-relevance (Q2) Q-square of 73.9\%. Qsquare predictive-relevance $(\mathrm{Q} 2)$ of $73.9 \%$ shows that the model built is well because it has a prediction relevance of $73.9 \%$. Thus the model that has been built is suitable for hypothesis testing.

\subsubsection{Path Coefficient Test}

Hypothesis testing is done by testing the path coefficient by the structural equation model. the results of the study can be seen in Table 4 as follows

Table 4, direct effect test

\begin{tabular}{lcccc}
\hline $\begin{array}{c}\text { Effect between } \\
\text { variables }\end{array}$ & $\begin{array}{c}\text { Path } \\
\text { coefficient }\end{array}$ & t-Statistics & P-Values & result \\
\hline FK-> FMB & 0.265 & 3.043 & 0.002 & Significant \\
\hline FK-> SC & 0.380 & 4.191 & 0.000 & Significant \\
\hline SC -> FMB & 0.316 & 3.531 & 0.000 & Significant \\
\hline FA -> FMB & 0.306 & 3.433 & 0.001 & Significant \\
\hline FA -> SC & 0.336 & 4.225 & 0.000 & Significant \\
\hline
\end{tabular}

Source: data processed

From table 4 it can be seen the results of the test of the direct effect of independent variables on the independent variables with the following results:

The direct effect of financial knowledge (FK) on financial management behavior (FMB) can be proven at the correlation coefficient value of 0.265 and $\mathrm{t}-$ statistic $>$ than t-table $(3.043>1,960)$ with a p-value $<$ than $0.05(0.002<0.05)$, thus it can be said that financial knowledge (FK) has a significant effect on financial management behavior (FMB).

The direct effect of financial knowledge (FK) on self-control (SC) can be proven at the correlation coefficient of 0.380 and the t-statistic value > of the t- 
table $(4.191>1,960)$ with a p-value $<0.05(0.000<0.05)$, thus it can be said that financial knowledge (FK) has a significant effect on self-control (SC)

The direct effect of self-control (SC) on financial management behavior (FMB) can be proven at the correlation coefficient value of 0.316 and t-statistic value $>$ of t-table $(3,531>1,960)$ with $p$-value $<0.05(0.000<0.05)$, thus it can be said self-control (SC) has a significant effect on financial management behavior (FMB).

The direct effect of financial attitudes (FA) on financial management behavior (FMB) can be proven at the correlation coefficient of 0.306 and the tstatistic value $>$ of t-table $(3,433>1,960)$ with a p-value $<$ of $0.05(0.001<0.05)$, thus it can be said that financial attitude (FA) significant effect on financial management behavior (FMB).

The direct effect of financial attitudes (FA) on self-control (SC) can be proven at the correlation coefficient of 0.336 and t-statistic value > of t-table $(4,225>$ $1,960)$ with $p$-value $<0.05(0,000<0.05)$, thus it can be said that financial attitude (FA) has a significant effect on self-control (SC).

\subsubsection{Indirect Effect Test}

Test results for indirect effects in this study can be seen in Table 5 below.

Table 5. Indirect effect test

\begin{tabular}{ccccc}
\hline Indirect effect & \multicolumn{2}{c}{ Direct Effect Test } & $\begin{array}{c}\text { Sobel Test } \\
\mathbf{1 . 9 6}\end{array}$ & Result \\
& & & Significant \\
\hline FK-> SC-> FMB & $\begin{array}{c}\text { FK-> SC } \\
=0.380\end{array}$ & $\begin{array}{c}\text { SC }>\text { FMB } \\
=0.316\end{array}$ & $\mathrm{t}=2.651$ & \\
& $\begin{array}{cccc}\text { FA-> SC } \\
\text { FA }>\text { FMB }\end{array}$ & $\mathrm{t}=2.685$ & Significant \\
& $=0.336$ & $=0.316$ & & \\
\hline
\end{tabular}

Source: data processed 
The test results of the indirect effect of financial knowledge (FK) on financial management behavior (FMB) through self-control (SC) can be proven on the value of the coefficient of the direct effect of financial knowledge (FK) on self-control (SC) of 0.380 (significant), the value of the direct effect of selfcontrol (SC) on financial management behavior (FMB) is 0.316 (significant), and coefficient of the direct effect of financial knowledge (FK) on financial management behavior (FMB) is 0.265 (significant). Sobel test state that the value of the indirect effect coefficient of financial knowledge (FK) on financial management behavior (FMB) through self-control (SC) of 2,651>1.96, thus it can be stated that self-control mediated the partial effect of financial knowledge (FK) on financial management behavior (FMB).

The test results of the indirect effect of financial attitudes (FA) on financial management behavior (FMB) through self-control (SC) can be proven in the coefficient of the direct influence of financial attitudes (FA) on self-control (SC) of 0.336 (significant), the direct effect of self-control (SC) on financial management behavior (FMB) was 0.316 (significant), and the coefficient value of the direct influence of financial attitude (FA) on financial management behavior (FMB) was 0.306 (significant). Sobel test states that the value of the indirect effect coefficient of financial attitude (FA) on financial management behavior (FMB) through self-control (SC) of 2,685> 1.96, thus it can be stated that self-control is mediated the partial effect of financial attitude (FA) on financial management behavior (FMB). 


\title{
4.2 DISCUSSION
}

\subsubsection{Effect of Financial Knowledge on Financial Management Behavior}

The results of the study stated that financial knowledge has a significant effect on financial management behavior. Thus it can be said that individuals who have high financial knowledge, will be able to allocate their finances and will form a strong control in themselves to resist the desire for consumptive purchases and be able to convince themselves in solving their financial problems so that these individuals try to carry out financial management either by setting aside some funds to pay bills on time.

This research is supported by research Purwidianti and Mudjiyanti (2016) state that individuals with higher financial knowledge tend to be wiser in their financial behavior. Likewise, research by Ida and Dwinta (2010) also states that financial knowledge has a significant effect on financial management behavior.

Thus the hypothesis proposed stating that financial knowledge has a significant effect on financial management behavior is proven.

\subsubsection{Effect of Financial Attitude on Financial Management Behavior}

This study states that financial attitude has a significant effect on financial management behavior. Thus it can be said that the better the financial attitude of a person, the better financial management. A good financial attitude can lead someone to manage various financial behaviors. Individuals who have financial attitudes will be better at managing their family finances.

This research is supported research by Pradiningtyas and Lukiastuti (2019) which states that financial attitudes have a significant effect on financial management behavior, Herdjiono and Damanik (2016) state that financial attitude has a significant effect on financial management behavior, Mien and Thao (2015) states that a person's financial attitude has a significant effect on financial

\author{
Vol. 28, No. 01 April 2020 \\ (C) Centre for Indonesian Accounting and Management Research \\ Postgraduate Program, Brawijaya University
}


management behavior. Thus the hypothesis which states that financial attitude has a significant effect on financial management behavior is proven.

\subsubsection{Effect of Self-Control on Financial Management Behavior}

This study states that self-control has a significant influence on financial management behavior. Self-control is related to how individuals control emotions and impulses from within themselves so that they can make decisions and take effective action according to ideal standards, moral values, and social expectations. The effect of self-control in financial management behavior is very important because, by the nature of self-control that exists in individuals, it will be a strategy used in preventing excessive waste and spending in financial allocations. The better a person is in controlling his finances, the better his financial management behavior.

This research is supported by Ida and Dwinta (2010) state that self-control has a significant effect on financial management behavior. Thus the hypothesis which states that self-control has a significant effect on financial management behavior is proven.

\subsubsection{Effect of Financial Knowledge on Self-Control}

This study states that financial knowledge has a significant effect on selfcontrol. The better the financial knowledge of individuals, the better they will manage their family finances. Individuals who have good financial knowledge will be able to make financial decisions in their families and be able to control their family's financial expenses and can set aside a portion of their funds to plan their family's future such as saving, insurance, and investing. That is because the individual has good financial knowledge and can manage their family finances wisely. 
This research is supported by Pradiningtyas and Lukiastuti (2019) state that financial knowledge has a significant effect on self-control. Thus the hypothesis which states that financial knowledge has a significant effect on self-control is proven

\subsubsection{Effect of Financial Attitude on Self-Control}

This study states that financial attitude has a significant effect on self-control. Financial attitude is more directed at individual thinking, income, and individual valuations about financial practices. Individuals who are rational and confident in financial matters will affect their self-control. Thus, it can be said that a person's financial attitude is also a factor influencing the way a person controls himself.

This research is supported by Pradiningtyas and Lukiastuti (2019) state that financial attitude has a significant effect on self-control. Thus the hypothesis which states that financial attitude has a significant effect on self-control is proven.

\subsubsection{Effect of Financial Knowledge on Financial Management Behavior Mediated Self-Control}

This study states that self-control partially mediated the effect of financial knowledge on financial management behavior. Thus it can be said that individuals who have good financial knowledge, will manage their finances, and can control themselves.

This research is supported by Perry and Morris (2005) state that the locus of control mediated the effect of financial knowledge on financial management behavior. Thus the hypothesis that states that self-control mediated effect of financial knowledge on financial management behavior is proven. 


\subsubsection{Effect of Financial Attitude on Financial Management Behavior Mediated Self-Control}

This study states that self-control partially mediated the effect of financial attitudes on financial management behavior. Thus it can be said the better of attitude individuals in finance will provide support to self-control in taking actions or decisions.

This research is supported by Pradiningtyas and Lukiastuti (2019) state that locus of control is mediated by the effect of financial attitude on financial management. Thus the hypothesis that states that self-control is a mediated effect of financial attitudes on financial management behavior is proven.

\section{CONCLUSIONS AND SUGGESTIONS}

This study aims to analyze the factors influencing financial management behavior in employees of Islamic University "45" Bekasi. The sampling technique used was purposive sampling, with a population of 305 employees and a sample taken 81 employees. The results of the study stated that financial knowledge has a significant effect on financial management behavior, the financial attitude has a significant effect on financial management behavior, selfcontrol has a significant effect on financial management behavior, financial knowledge has a significant effect on self-control, the financial attitude has a significant effect on self-control, self-control can be the partial mediating effect of financial knowledge on financial management behavior, and self-control can be the partial mediating effect of financial attitudes on financial management behavior. 


\subsection{Limitations and Suggestions for Future Research}

Limitations in this study are the population and the sample used in this study is limited to employees of the Islamic University of "45" Bekasi. For future researchers are advised to replicate this research by using different research objects and samples, and added independent variables to get better results of the research. 


\section{REFERENCES}

Camilla Strömbäck, Thérèse Lind, Kenny Skagerlund, DanielVästfjäll, Gustav Tinghög. Lusardi. (2017). Doesself-control predict financial behavior and financial well-being? Journal of Behavioral and Experimental Finance, 14, 30-38. https://idx.doi.org/10.1016/j.jbef.2017.04.002

Chaplin, J.P. (2011). Kamus Lengkap Psikologi. Jakarta: Raja Grafindo Persada Chandra, Abhijeet. (2009). Individual investor's trading behavior and the competence effect. Journal of Behavioral Finance, 6(1), 215-30. https://doi.org/10.1016/j.jcorpfin.2007.04.011

Chen-Chen Yonga, Siew-Yong Yewb, dan Chu-Kok Weec (2018) Financial Knowledge, Attitude and Behaviour of Young Working Adults in Malaysia. Institutions and Economies, 10(4), 21- 48

Dew, Jeffery, dan Xiao Jing Jian. (2011). The Financial Management Behavior Scale: Development and Validation. Journal of Financial Counseling and Planning. 22, 43-59.

Gerungan. (2000). Psikologi Sosial. Bandung: Refika Aditama

Ghozali, Imam. (2006). Aplikasi Analisisi Multivariat Dengan Program SPSS (Application of Multivariate Analysis with the SPSS Program). Edisi 3. Andi: Yogyakarta

Ghufron, M. Nur dan Rini Risnawita S. (2011). Teori-teori psikologi (Psychology theories). Yogyakarta: Arr-Ruzz Media

Graham, John R, Harvey, Campbell R, and Huang Hai. (2009). Investor competence, trading frequency, home bias. Management Science, 55(7), 205-235. https://doi.org/10.1287/mnsc. 1090.1009

Herdjiono, Irine dan Damanik, Angela. (2016). Pengaruh Finacial Attitude, financial knowledge, parental income terhadap financial management behavior (Effect of Financial Attitude, financial knowledge, parental income 
on financial management behavior). Jurnal Management Teori dan Terapan, 5(3), 226-241. http://dx.doi.org/10.20473/jmtt.v9i3.3077

Herlindawati, Dwi. (2015). Pengaruh kontrol diri, jenis kelamin, dan pendapatan terhadap pengelolaan keuangan pribadi mahasiswa Pascasarjana Universitas Negeri Surabaya (The effect of self-control, gender, and income on the personal financial management of postgraduate students at Universitas Negeri Surabaya). Jurnal Ekonomi Pendidikan dan Kewirausahaan. 3(1), 158-169. http://dx.doi.org/10.26740/jepk.v3n2.p158-169

Hilgert, Marianne A., Jeanne M.Hogarth dan Sondra Baverly. (2003). Household Financial Management: The Connection between Knowledge and Behavior. Federal Reserve Bulletin, 89(7), 309-322

Hofmann, Baumeister, Förster dan Vohs. (2012). Everyday Temptations: An Experience Sampling Study of Desire, Conflict, and Self-Control. Journal of Personality and Social Psychology, 6(102), 1318-1335

Horne, James C. Van and Wachowicz John M. Jr. (2005). Fundamental of Financial Management. Buku 1, edisi 4. Jakarta: Salemba Empat Hung Angela A., Parker Andrew .M, Yoong Joanne K (2009). Defining and Measuring Financial Literacy. Labor And Population Working Paper Ida dan Dwinta, Chintia Yohana. (2010). Pengaruh locus of control, financial knowledge, dan income terhadap financial management behavior (The effect of locus of control, financial knowledge, and income on financial management behavior). Jurnal Bisnis dan Akuntansi, 12(3), 131 144. http://dx.doi.org/10.20473/jmtt.v9i3.3077

Kholilah, Naila Al dan Iramani, Rr. (2013). Studi Financial Management Behavior Pada Masyarakat Surabaya (Study Financial Management Behavior in Surabaya Society). Journal of Business and Banking, 3(1), 2533 
Lynne M. Borden, Sun-A Lee, Joyce Serido, Dawn Collins (2008). Changing College Students' Financial Knowledge, Attitudes, and Behavior through Seminar Participation. Journal of Family and Economic Issues. 29, 23-40. https://doi.org/10.1007/s10834-007-9087-2

Marsh, Brent A. (2006). Examining the personal finanial attitudes, behavior and knowledge levels of first-year and senior students at Baptist Universities in the State of Texas. Bowling Green State University

Madern, Tamara, Schors Anna Van Der. (2012). Financial attitudes and skills as early-warning signs of financial problems. Dutch National Institute for Family Finance Information

Mien, Nguyen Thi Ngoc dan Thao Tran Phuong. (2015). Factors Affecting Personal Financial Management Behaviors: Evidence from Vietnam. Proceedings of the Second Asia-Pacific Conference on Global Business, Economics, Finance and Social Sciences (AP15 Vietnam Conference)

Naomi Prima dan Mayasari, Iin. (2008). Pengaruh Kontrol Diri Terhadap Perilaku Pembelian Kompulsif (Effect of Self-Control on Compulsive Buying Behavior) . Telaah Bisnis, 9(2), 179-193.

Otto, Philip E, Davies G.B., Chater, N. (2007). Note on Ways of Saving: Mental Mechanisms as Tools for Self-Control. Global Business and Economic Review, 9(2), 315-345. https://doi.org/10.1504/GBER.2007.013703

Pankow Debra. (2003). Financial Values, Attitud and Goals, North Dakota State University Fargo, North Dakota.

Perry, V. G., dan Morris, M. D. (2005). Who is in control? The role of selfperception, knowledge, and income in explaining consumer financial behavior. The Journal of Consumer Affairs, 39(2), 299313. https://doi.org/10.1111/j.1745-6606.2005.00016.x 
Prihartono, M. Rizky Dwi and Asandimitra, Nadia. (2018). Analysis Factors Influencing Financial Management Behaviour. International Journal of Academic Research in Business and Social Sciences, 8(8), 308-326. http://dx.doi.org/10.6007/IJARBSS/v8-i8/4471.

Purwidianti, Wida dan Mudjiyanti, Rini (2016) Analisis pengaruh pengalaman keuangan dan tingkat pendapatan terhadap perilaku keuangan keluarga di Kecamatan Purwokerto Timur (Analysis effect financial experience and income level on family financial behavior in District of East Purwokerto). Benefit, Jurnal Manajemen dan Bisnis, 1(2), 141-148. https://doi.org/10.23917/benefit.v1i2.3257

Pompian M. M. (2006). "Behavioral financial and wealth management". Hoboken. New Jersey: John Wiley \& Sons, Inc.

Sabri Mohamad Fazli, MacDonald Maurice, Masud Jariah, Paim Laily, Hira Tahira K., Othman Mohd. Amim (2008). Financial Behavior and Problems among College Students in Malaysia: Research and Education Implication. Consumer Interests Annual, 5(4), 166-170

Shohib, Muhammad. (2015). Sikap Terhadap Uang dan Perilaku Berhutang (Attitudes Towards Money and Debt Behavior). Jurnal Psikologi Ilmiah Terapan, 3(1),215-240

Tifani Enno Pradiningtyas dan Fitri Lukiastuti (2019). Pengaruh pengetahuan keuangan dan sikap keuangan terhadap locus of control dan Perilaku pengelolaan keuangan mahasiswa ekonomi (Effect of financial knowledge and financial attitudes on locus of control and financial management behavior of economics student). Jurnal Minds: Manajemen Ide dan Inspirasi, 6(1), 96-112. https://doi.org/10.24252/minds.v6i1.9274

Wibisono, Okky Putri. (2013). Pengaruh Kompetensi Dan Kepercayaan Diri Investor Terhadap Perilaku Perdagangan Saham (Effect of Competence and 
Investor Confidence on Stock Trading Behavior). Journal of Business and Banking, 3(1), 56-71. http://dx.doi.org/10.14414/jbb.v3i1.253 
